\title{
Review
}

\section{Pax Gandhiana: The political philosophy of Mahatma Gandhi}

\author{
Anthony J. Parel \\ Oxford University Press, New York, 2016, xii + 220 pp., \\ ISBN: 978-0190491451
}

Contemporary Political Theory (2019) 18, S110-S113. https://doi.org/10.1057/s41296018-0191-x; published online 18 January 2018

If Gandhi's political philosophy were realized, argues noted Gandhi scholar Anthony Parel in his new book, Indians would be liberated not just from British colonial rule, but also from the spiritually damaging modes and orders of Western civilization and their own past. Gandhi's political philosophy integrates the ethical, the moral, the aesthetic, and the spiritual into a political way of being that is not only best suited for India's transition from colony to independent nation, but also implicitly offers a standing critique of what Western politics was, is, and seems destined to be. Parel's account reorients our understanding of Gandhi away from its preoccupation with a particular form of non-violence and from the Western political frameworks (liberal, Marxist, postcolonial, socialist, etc.) that have insisted upon that preoccupation. By taking the Indian purusharthas (the four ends of human life) as his own frame for understanding Gandhi's voluminous but unsystematic work, Parel is able to map out the work of a thinker whose political philosophy enabled comprehension, critique, and provided the basis for, in fact insisted upon, concrete action in the world.

The scope and execution of Parel's project is impressive. The unsystematic nature of Gandhi's work issues from his ongoing engagement in the practical politics of his day. Consequently, Parel observes the subtle - and not so subtle changes in emphasis in Gandhi's work over time, tying them to events in India, particularly the emerging national consciousness of its people, the complications arising therefrom, and the institutional manifestations of that emergence. Part intellectual history, then, Parel's work traces Gandhi's engagements with texts and thinkers in the Indian canon, which he divides into 'old' (the Upanishads and the Bhagavad Gita, etc.) and 'new' (Tagore, Jinnah, etc.) and the Western canon, from an opening comparison with Machiavelli, to Gandhi's own encounters with figures like Thoreau and Ruskin. In Parel's hands, these encounters shape Gandhi's readings of his changing political environment and his understanding of his own role in it. While there is a tendency to move quickly through these encounters, often

(c) 2018 Macmillan Publishers Ltd., part of Springer Nature. 1470-8914 Contemporary Political Theory Vol. 18, S2, S110-S113 www.palgrave.com/journals 
noting rather than pursuing the implications of Gandhi's (dis-) agreements with these thinkers, that seems to be a part of the project's nature. Parel is covering a lot of ground in a very short space (200 pages) and should be read as very adroitly mapping out a territory. As a critical partisan of the Gandhi he finds, Parel is working in the mode of articulation. What he articulates is what he calls Pax Gandhiana, a mode of political being that he hopes is practical, but that is most decidedly more humane than what either Gandhi or Parel find at work in their respective worlds.

Parel identifies Pax Gandhiana as a social and political 'order of freedom and peace' grounded in 'truth' that will manifest itself with the implementation of Gandhi's political philosophy (p. 11). It is not, because it cannot be, an order of absolute non-violence. While non-violence was instrumental in resisting and overcoming British rule, Parel's Gandhi domesticates it into a way of meeting local, civic obligations - once liberation is achieved and Gandhi turned his attention to practical political and economic matters. Gandhi discusses and critiques the emerging order in familiar terms. Throughout his account, Parel shows how Gandhi persistently reclaimed and reinterpreted ideas from his own tradition and melded them with ideas - especially critical ones - inherited from the West. In the case of Pax Gandhiana, the new state should embody a purposive social and political order. The state retains its coercive power, but exercises it only within constitutional limits established by and through consent of the governed. It should engage non-violent NGOs in what Gandhi called the Constructive Programme, generating an ethos of service ( $\operatorname{eva}$ ) that would inform a variety of necessary human activities, including constructive work. Civil disobedience of the type that resisted and overcame empire would only be necessary in local matters, for properly oriented institutions and honest public official would obviate the need for it at the national level. Finally, the struggle for political power would be a matter of party politics played out against a backdrop of free and fair elections (p. 136). But this renewed political environment would not emerge without concentrated effort and self-discipline, and Parel walks the reader through this intensive but rewarding Gandhian project.

Unlike some of his contemporaries, Gandhi does not shy away from the idea that political life should be both humane and purposive. A Gandhian social and political order will provide for the development of the full humanity of its subject participants, but this will require reorienting all action to what Gandhi calls 'truth.' At the outset this term 'truth' might be suspect to Western ears, coming as it does with assumptions about power and possession. Parel's Gandhi, however, would insist that our suspicions of truth derive from our perspective as subjects and participants in Western politics and civilization. In the West, truth aligns with political and military power, as something possessed, to be imposed upon others for their own good, whether they like it or not. As such, it comes cloaked in the guises of colonialism and cultural imperialism, à la Pax Britannica. Parel demonstrates

(C) 2018 Macmillan Publishers Ltd., part of Springer Nature. 1470-8914 Contemporary Political Theory Vol. 18, S2, S110-S113 S111 
that for Gandhi, however, appropriate social and political practices, let alone institutions, will only derive from pursuit of the truth that involves working on and through each of the four dimensions of distinctly human existence in the Indian tradition. Parel describes these as 'the canonical ends of life - ethics (dharma with its emphasis upon duty), economic prosperity and democratic politics (artha), the forms of pleasure (kama) and the pursuit of spiritual transcendence (moksha)' (p. vii). The challenge of Pax Gandhiana - as both a critique and a way of political being - lies in cultivating and integrating each of these into each human life. Only in this pursuit would the emerging political order of India be humane and avoid both the errors of its caste-ridden past and the pitfalls of the contemporary West.

Drawing upon the idea of the harmonious relationship between sense and soul found in the Bhagavad Gita, the core of Gandhi's political philosophy is discipline of self and community. Indeed, this is the idea that links it to active engagement in the world. We find the focus on discipline in Parel's emphasis upon swaraj as well as his reading of Gandhi's evolving understanding of satyagraha. Swaraj, or selfrule, takes two forms here: political and spiritual. Parel traces political swaraj through a variety of forms in Gandhi's thought as he spearheads the Indian fight for independence. 'Political swaraj,' finally achieved in 1947, 'secures the collective freedom of the nation,' Parel writes, 'and protects and promotes the rights of every individual living in the country' (p. 92). But Gandhi knows well that anticolonial struggles can unleash passions that cannot be controlled once political independence is achieved, so the second form of discipline was a critical component of his vision of a liberated India. Spiritual swaraj involves rule from within and requires the internal spiritual freedom in which the senses and the soul work together. Parel associates this form of swaraj in a kind of negative freedom, that is, freedom from both external and internal impediments. Once the external are overcome, the internal must be the focus of the struggle. For Parel's Gandhi, discipline, that is, drawing the two forms of swaraj together, was essential in making the transition from colony to nation, from colonial to citizen. Swaraj 'as self-rule helps to create a disciplined citizenry,' (p. 92) he argues, so that liberated citizenship, like humanity itself, is an ongoing project.

In Parel's hands, Gandhi's political philosophy, his arthasastra, 'puts an end to the old chakravartin concept of the imperial state' and in so doing 'changes the very notion of political power from one that seeks to expand limitlessly to one that limits itself to the requirements of internal order, world peace, interdependence, and universal dharma' (p. 69). This reorientation of politics away from body-force to soul-force, away from materialism and physical power to spiritual discipline, creativity, and inner strength, is very appealing, but also exceedingly difficult. Over and again, Parel insists that Gandhi's vision is not utopian, and the sympathetic reader is inclined to take him at his word. Nonetheless, Gandhi challenges and reinterprets important assumptions about political and economic order, and each challenge represents a risk: a politics of purpose that is about human being and not

S112 (C) 2018 Macmillan Publishers Ltd., part of Springer Nature. 1470-8914 Contemporary Political Theory Vol. 18, S2, S110-S113 
power; a coercive state that nonetheless restrains itself; a civic nationalism that must resist the temptation of xenophobia; an economic order that values work over the acquisition of wealth for its own sake, reclaiming the spiritual without falling to the pressures of intolerance in a charged and complex religious environment. These challenges are all too familiar. Parel's account of Gandhi's political philosophy demands those of us confronted by those challenges to take risks while embracing its requirement of self-discipline. In this way, Parel's account of Gandhi offers much more than a political philosophy. It may well offer a philosophy of political engagement - demanding to be engaged.

John Randolph LeBlanc University of Texas at Tyler, Tyler, TX 75799, USA rleblanc@uttyler.edu 